\title{
OSOBA - DUSZA - MÓZG. CO GWARANTUJE STATUS ONTOLOGICZNY CZŁOWIEKA
}

\section{WHAT ENSURES MAN'S ONTOLOGICAL STATUS: THE PERSON, THE SOUL, OR THE BRAIN?}

The concept of man's ontological status, which is being hotly debated in current discussions on the relationship between the mind and the body, has its roots in European thought. This article indicates where answers to the question of the man's ontological status in the context of the current cultural mindbody debate can be found. Since the history of the mind-body debate is long and extremely rich, the following anthropological terms that were defined in Western antiquity will serve as a backdrop for the reflections presented below: 1) the soul as the material part of the human body, which is the starting point for later reductionist views; 2 ) the soul as an immaterial and immortal reality imprisoned in the human body, which gives rise to dualistic definitions of man;

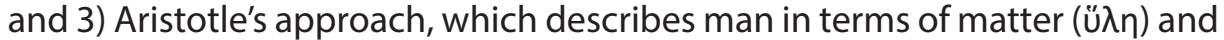
form ( $\mu$ о $\phi \eta)$, where the soul is neither reduced to the material parts of the body nor treated as a separate substance present in the body. A response to the question regarding man's ontological status will be formulated in light of the theoretical similarities between Aristotelian and Thomistic philosophies and the natural sciences, especially current physical theories (quantum field theory, QFT) and different kinds of research on the human brain (brain neural field studies).

Key words: human soul, hylomorphism, ontology, anthropology, neuroscience, quantum field theory. 


\section{Wstęp}

Już od starożytnych czasów na wiele sposobów wyrażane było przekonanie na temat wyjątkowego charakteru życia człowieka. Intuicja ta rodziła się i ugruntowywała na skutek coraz bardziej systematycznej refleksji nad zagadnieniem ludzkiej moralności, kwestii nieśmiertelności duszy, czy różnych przejawów wewnętrznego, tj. duchowego życia człowieka. Te antropologiczne przekonania znalazły również swój wyraz na płaszczyźnie etymologicznej obecnej w greckiej i rzymskiej tradycji filozoficznej. Greckie pojęcia psyché, ánemos, pnêuma, czy też ich łacińskie tłumaczenia anima, spiritus wyrażają owo głębokie przekonanie o istnieniu w człowieku pewnego dynamicznego (niczym oddech, wiatr, tchnienie) elementu, który jednak nie daje się łatwo definiować ${ }^{1}$. W konsekwencji bycie człowiekiem jawiło się już u zarania myśli filozoficznej jako coś bezpośrednio danego (aspekt materialny), ale zarazem trudnego do ujęcia (aspekt duchowy). W epoce nowożytnej zagadnienie duszy zostało zastąpione pojęciem umysłu (mind), stąd tak żywo dziś podejmowany w antropologicznych debatach tzw. mind-body problem².

Celem niniejszego artykułu jest próba wskazania kierunku poszukiwania odpowiedzi na postawione pytanie o status ontologiczny człowieka w kontekście aktualnej, kulturowej debaty. Już w starożytności zostały wytyczone trzy zasadnicze nurty antropologicznego myślenia. Pierwszy, reprezentowany przez Epikura i Demokryta, opisywał duszę jako materialną część ludzkiego ciała. Stąd można go określić jako wzorzec dla późniejszych ujęć redukcjonistycznych. Drugi, znalazł maksymalny wyraz w myśli Platona, ujmował duszę jako niematerialną i nieśmiertelną rzeczywistość uwięzioną w ludzkim ciele. Stąd późniejsze dualistyczne ujęcia człowieka. Wreszcie trzeci nurt, rozwinięty przez Arystotelesa, różny od dwóch powyższych, ujmujący problem ludzkiego bytu

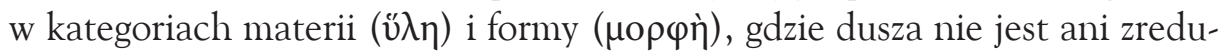
kowana do materialnych części ciała, ani nie jest traktowana jako oddzielna substancja obecna w ciele ${ }^{3}$. Na wstępie dokonuje się zatem dwóch zasadniczych ograniczeń pola prowadzonych refleksji. Po pierwsze, ponieważ historia debaty mind-body jest długa i niezwykle bogata, odsyłamy do odpowiedniej literatury, a powyżej nakreślona „mapa antropologicznych ujęć” będzie stanowić tło dla refleksji zawartych w artykule. Po drugie, próba odpowiedzi na tytułowe

$1 \quad$ Zob. P. Manganaro, Phenomenology and Neuroscience. Living Experience, Empathy and Embodied simulation, [w:] COMPRENDRE. Archive International pour l'Anthropologie et la Psychopathologie Phénoménologiques, Padova 2010, s. 153-165.

2 Por. J. Bremer, Wprowadzenie do filozofii umystu, Kraków 2010, s. 38-51.

3 Por.J.J.Sanguineti, Operazioni cognitive: un approccio ontologico al problema mente-cervello, w ActaPhilosophica, II, 14 (2005), Pisa - Roma, s. 233-258. 
zagadnienie będzie formułowana w kontekście aktualnego dialogu filozofii nurtu arystotelesowsko-tomistycznego z naukami przyrodniczymi, zwłaszcza w odniesieniu do aktualnych teorii fizycznych (kwantowa teoria pola, ang. quantum field theory (QFT)) i kierunków badań nad ludzkim mózgiem (badanie mózgowych pól neuronalnych).

\section{Dwie epistemologie}

Aby zrozumieć trudności w dialogu filozofii arystotelesowsko-tomistycznej ze współczesnymi naukami przyrodniczymi należy podkreślić głęboką różnicę istniejącą pomiędzy metodą nauk nowożytnych a właściwą filozofii arystotelesowsko-tomistycznej. Tę pierwszą można określić jako analityczno/apodyktyczno-dedukcyjną, która na skutek przemian na łonie nauki w XX wieku stała się hipotetyczno-dedukcyjną, zaś druga korzysta z metody abstrakcji. Wraz $z$ rozwojem fizyki Newtona i towarzyszącej jej refleksji filozoficznej przyrodoznawstwo, a zwłaszcza fizyka, w mniejszym stopniu niż dotychczas interesowało się naturą, istotą badanych obiektów, a także przyczynami wywołującymi ich powstanie ${ }^{4}$. W ten sposób wyjaśnienie naukowe stało się nie poszukiwaniem przyczyn, które w kontekście nowej metody jawiły się jako „niejasne”, ale poszukiwaniem praw geometrycznych i odpowiadających im równań algebraicznych, rządzących zmianami pewnej wielkości (zmienna zależna) wobec zmian innej wielkości (zmienna niezależna). Zatem tzw. matematyczno-empiryczne badanie przyrody oznaczało wyjaśnianie zjawisk, fenomenów poprzez znalezienie odpowiedniego, uniwersalnego prawa matematycznego pozwalającego na przewidywanie występowania zjawisk. W ten sposób pojęcie prawa (cognitio certa per leges) zastąpiło klasyczne pojęcie przyczyny (cognitio certa per causas) ${ }^{5}$.

Z pewnością niezwykła efektywność nowożytnej epistemologii ${ }^{6}$ zasadza się na typowym dla niej „ascetyzmie” metodologicznym. Co nie poddaje się owej metodzie, nie staje się obiektem badań przyrodniczych ${ }^{7}$. Jednak owa efektywność wyjaśnień możliwa była w oparciu o „pominięcie” oddziaływania

4 Por. I. Newton, Opticks, London 1730, s. 376-377; idem, Scolio generale, [w:] Principi matematici della Filosofia Naturale (red. A. Pala), Milano 2008, s. 797-802.

5 Zob. G. Basti, Filosofia dell'uomo, Roma 2008, s. 24-25; J. Maritain, Distinguere per unire. I gradi del sapere, Brescia 1974, s. 44-45.

6 Pod tym pojęciem rozumie się dział logiki i filozofii, który bada fundamenty i metody typowe dla poznania naukowego. W ten sposób epistemologia różni się od ogólnie pojętej gnozeologii, czy filozofii poznania.

7 Zob. M. Heller, Filozofia nauki. Wprowadzenie, Kraków 2009, s. 101-102. Por. R. Audi, Naturalism as a Philosophical and Scientific Framework. A Critical Perspective, [w:] Between Philosophy and Science M. Heller, B. Brożek, Ł. Kurek (red.), Kraków 2013, s. 11-21. 
badanych obiektów $z$ ich otoczeniem, środowiskiem. Z ontologicznego punktu widzenia oznacza to mechanistyczną interpretację badanych układów: separacja cząstek od sił na nie oddziałujących, gdzie wyjaśnienie ruchu tych pierwszych zostaje przedstawione $\mathrm{w}$ formie praw geometrycznych tym ruchem rządzących ${ }^{8}$. Następnie w trakcie rozwoju nowożytnej fizyki pryncypium to zostało uogólnione na dynamikę systemów złożonych przy użyciu tzw. teorii perturbacji. W ogólności, teoria ta stosowana w kontekście dynamiki wielu ciał (obecnie również w ramach nieliniowych systemów mechaniki statystycznej jak i w ramach mechaniki kwantowej) wyraża tę samą strategię epistemologiczną i ontologiczną. Dynamika, czyli wyjaśnianie przyczynowe ruchów jako interakcji pomiędzy ciałami, zostaje zredukowana do opisu kinematycznego ruchu, czyli matematycznego wyjaśnienia badanych zjawisk w terminach praw przyrody ${ }^{9}$. $\mathrm{Na}$ skutek przemian wywołanych odkryciem geometrii nieeuklidesowych niekwestionowana wcześniej ważność postulatów geometrii euklidesowej w matematyce i praw mechaniki newtonowskiej w fizyce zostały zachwiane. Metoda analityczno/apodyktyczno-dedukcyjna oparta na jasności i oczywistości jedynego zbioru wyjściowych aksjomatów przekształciła się w metodę hipotetyczno-dedukcyjną, gdzie nauka formułując wyjściowe hipotezy dotyczące świata, następnie na skutek empirycznej kontroli falsyfikuje je lub nie ${ }^{10}$. W przeciwieństwie do metody nauk nowożytnych epistemologia arystotelesowsko-tomistyczna skoncentrowana pozostaje na metodzie abstrakcji. Oznacza to, że idee, definicje, które stanowią podstawę sformułowania późniejszych praw, czy przesłanki większej dla określonego rozumowania dedukcyjnego wyrażają relację logiczną, która koresponduje z daną relacją przyczynową w realnym porządku. To właśnie proces abstrakcji pozwala na przejście od konkretnej, pojedynczej relacji przyczynowej pomiędzy bytami (lub różnymi częściami bytu) do uniwersalnego charakteru relacji logicznej, która

8 Zob. M. Planck, La posizione della nuova fisica di fronte alla visione meccanicistica della natura, [w:] Scienza, filosofia e religione F. Selvaggi (red.), Milano 1965, s. 147-165. Obecnie znamy w przyrodzie cztery rodzaje sił: grawitacyjną, elektromagnetyczną, słabą i silną. Wszystkie utożsamiane są z cząstkami elementarnymi: grawitonami, fotonami, bozonami W i Z, gluonami. Innymi cząstkami elementarnymi są: kwarki, leptomy, bozon Higgsa.

Zob. G. Basti, L'idea di scienza di Maritain tra passato e futuro, [w:] Aquinas LVIII (2015), s. $117-165$.

10 Zob. G. Basti, Filosofia dell'uomo, s. 27-28. Pozostaje jednak w kontekście epistemologii nauk otwartą kwestią problem wyboru wyjściowych aksjomatów. A także nie można zapomnieć, z czego już zdali sobie sprawę w starożytności logicy ze szkoły stoickiej, że prawdziwe wnioski w ramach rozumowania hipotetycznego nie mogą nigdy potwierdzić prawdziwości przesłanki, jako że prawdziwe wnioski równie dobrze mogą wypływać z fałszywych przesłanek (tzw. błąd następnika). Natomiast fałszywość wniosków również falsyfikuje przesłankę (ibidem, s. 40). Stąd wypływa teoretyczne umocowanie Popperowskiego falsyfikacjonizmu w kontekście współczesnego przyrodoznawstwa. 
wyraża konieczność relacji przyczynowej przez konieczne powiązanie przesłanki/ wniosku lub podmiotu/predykatu. Zasadnicza różnica pomiędzy obiema epistemologiami nie opiera się więc na wykorzystaniu matematyki lub nie ${ }^{11}$, ale zasadza się na systematycznym pomijaniu w epistemologii nowożytnej rozważań nad bytami i ich przypadłościami (jakość, ilość, relacje) oraz na przyjmowaniu kryterium apodyktyczności bądź hipotetyczności przesłanek w odróżnieniu od ich indukcyjnego ufundowania w ramach nauki arystotelesowskiej. Właśnie w ramach tej ostatniej dedukcje nauk przyrodniczych znajdują swoje oparcie w relacji przyczynowej, zwłaszcza w jej sformułowaniu formalno-finalnym, na podstawie której na drodze abstrakcji jest formułowane pewne przyrodnicze prawo. Zatem dopiero określona a posteriori relacja przyczynowa pomiędzy pewnym zbiorem tzw. przyczyn początkowych danego procesu fizycznego i ich efektem końcowym stanowi podstawę dla logicznego sformułowania koniecznego charakteru danego związku przyczynowego ${ }^{12}$. Aby jeszcze lepiej

11 Tomasz z Akwinu w komentarzu do Analityk Wtórnych (Expositio Posteriorum, lib. I, 1. 1 n. 10), omawiając problem statusu nauki, wyraża przekonanie o niedoścignionym wzorze metody matematycznej pośród nauk dedukcyjnych, gwarantującym wyjątkową pewność jej rozumowań (,principaliores sunt mathematicae scientiae, propter certissimum modum demonstrationis").

12 Zob. G. Basti, Filosofia dell'uomo, s. 28-32. Tomasz z Akwinu w swoim komentarzu do Fizyki Arystotelesa (In Physic., lib. 2 1. 11, 1-9), dokonując uważnej lektury Filozofa, podkreśla, że dla dokładnego określenia danego procesu fizycznego nie zawsze jest konieczne wskazanie wszystkich czterech przyczyn, gdyż w niektórych przypadkach wystarczy wskazać przyczyny początkowe (sprawczą i materialną), aby jednoznacznie określić stan końcowy danego zjawiska. W takim przypadku nie ma potrzeby przywoływania przyczyny formalno-finalnej, gdyż zasadniczo cztery przyczyny zostają zredukowane do dwóch początkowych. To właśnie póńniejsza filozofia mechanistyczna ograniczy się jedynie do wskazywania tych dwóch przyczyn początkowych, ujmując je w formie tzw. warunków początkowych, czyli procedury analityczno-dedukcyjnej, gdzie z pewnych mierzalnych wielkości, przez ich wzajemne powiązanie za pomocą matematycznych funkcji, dedukuje się zmienne wartości podlegające późniejszej empirycznej weryfikacji. Zasadnicza różnica międ zy dwoma ujęciami polega na tym, że u Arystotelesa mamy do czynienia z podejściem indukcyjnym, w drugim zaś ujęciu mamy podejście analityczne w kwestii problemu ufundowania prawa/aksjomatów. Dlatego św. Tomasz posuwa się dalej w swoim komentarzu wskazując na fakt, że w większości zjawisk badanych przez nauki przyrodnicze wielość przyczyn początkowych nie determinuje jednoznacznie stanu końcowego procesu. Co więcej stan początkowy może determinować wiele różnych stanów końcowych, czyli stwarzać możliwość zaistnienia różnych efektów. Stany końcowe, jak komentuje Tomasz, będą produkowane przez przyczyny początkowe tylko z określoną częstotliwością (frequenter), prawdopodobieństwem. Z drugiej jednak strony owa dwuznaczność relacji przyczyna-efekt, w odniesieniu do stanu początkowego, zostaje usunięta przez proces fizyczny, w tym sensie, że jeśli jakieś zjawisko zaszło, zatem a posteriori zaszło w sposób konieczny. Innymi słowy, to nie jedynie wielość przyczyn początkowych wyprodukowała dany skutek, ale również realne zaistnienie skutków, tj. zaistnienie całego procesu, jednoznacznie określa relację istniejącą między stanem początkowym a końcowym. Mówiąc obrazowo, to tak jakby 
zrozumieć sens metody abstrakcji w ramach epistemologii arystotelesowsko-tomistycznej należy pokrótce przypomnieć już wspomnianą arystotelesowską doktrynę przyczynowości, a zwłaszcza przyczyny formalno-finalnej, która została zdyskredytowana zwłaszcza w okresie nowożytnym.

\section{Problem przyczynowości}

W epoce nowożytnej pojęcie przyczyny przede wszystkim stało się synonimem pojęcia siły, a dokładniej pojęcia działania, akcji, tj. działania siły w określonym czasie i przez to modyfikującej stan inercjalny ruchu lub spoczynku danego ciała. Tymczasem dla Arystotelesa cztery przyczyny stanowiły przede wszystkim cztery sposoby sformułowania pytania „dlaczego” (ö ı), na które filozof przyrody musiał odpowiedzieć, aby mógł w sposób wystarczający określić istotę danego bytu, jego powstawania. Tak więc, gdy dla nauki nowożytnej siła jest pewną mierzalną wielkością ${ }^{13}$, dla Arystotelesa przyczyna sprawcza to byt, aktywny podmiot działania przyczynowego. Przyczyna materialna, według Arystotelesa, może być określona jako materialny, pasywny substrat poddany działaniu przyczyny sprawczej. Jednak odpowiednikiem tej przyczyny nie może być nowożytne pojęcie materii ${ }^{14}$. W ujęciu arystotelesowskim materia bowiem była ukonstytuowana przez nieustający ruch elementów stanowiących materialny substrat. Owe elementy obdarzone są siłami, pewnymi własnościami aktywno-pasywnymi, zasadniczo dającymi się sprowadzić do ciepła, wzajemnie na siebie oddziałującymi. Dla uzupełnienia arystotelesowskiego rozumienia materii należy w tym miejscu wspomnieć pojęcie materii pierwszej ( $\pi \rho \omega ́ \tau \eta \eta$

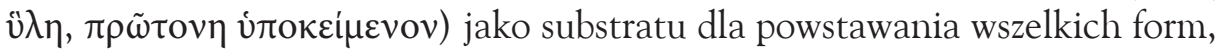
uzasadniającego fakt przekształcania się w przyrodzie jednych elementów (ziemia, powietrze, ogień, woda) w inne. W ten oto sposób zewnętrzna przyczyna sprawcza, zdaniem Filozofa, jest w stanie indukować nieodwracalny proces ukierunkowany na osiągnięcie nowej, mniej lub bardziej uporządkowanej stabilności. Dlatego właśnie nowa forma (substancjalna lub akcydentalna)

sam proces fizyczny, dopiero po swoim efektywnym zaistnieniu, „określił sam siebie”. W związku z tym to, co dane prawo naturalne wyraża a priori, mogło zostać tak określone jedynie w oparciu o obserwację a posteriori danego zjawiska. Pogłębione studium tego zagadnienia z punktu widzenia metafizycznego i metalogicznego wraz z próbą formalnego ujęcia przyczynowości finalnej w kontekście epistemologii arystotelesowsko-tomistycznej w G. Basti, Lontologia formale del «realismo naturale», cosmologia evolutiva e partecipazione dell'essere, [w:] Divus Thomas 117-2 (2014), s. 276-283; G. Basti, A.L. Perrone, Le radici forti del pensiero debole. Dalla metafisica, alla matematica, al calcolo, Padova - Roma 1995.

13 Pojęcie siły odpowiadałaby raczej arystotelesowskiemu virtus.

14 Zob. M. Heller, Bóg i materia, [w:] M. Heller, J. Życiński i in., Wszechświat-Maszyna czy myśl, Kraków 2014, s. 121-135. 
wyprowadzona na skutek oddziaływania przyczynowego z substratu material-

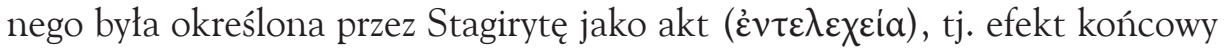
ustabilizowanego ruchu elementów substratu na skutek działania causa efficiens. Zatem działanie przyczyny sprawczej, najpierw „destabilizujące” wcześniejszą formę organizującą dynamikę danego ciała, jego substratu, następnie powoduje zmianę substancjalną lub akcydentalną, czyli powołuje do istnienia nową formę uporządkowania materii ${ }^{15}$.

Nieodwracalność procesu powstawania nowej formy ściśle związana jest $z$ kluczową rolą ciepła $\mathrm{w}$ arystotelesowskim rozumieniu zjawisk przyrodniczych $^{16}$. To, co zostało pominięte w nowożytnej lekturze arystotelesowskiej philosophia naturalis to odczytanie arystotelesowskiej dynamiki w kluczu termodynamiki. Filozof podkreślał, zwłaszcza w De Caelo et Mundo oraz De Generatione et Corruptione, że następująca w procesach naturalnych wymiana ciepła, oprócz łączenia elementów sobie podobnych i oddzielenia tych niepodobnych, indukuje kierunek preferencyjny ruchu ciał. Ciepło według Filozofa jest tym, co sprawia, że ruch cząsteczek cieplejszych zachodzi w kierunku krańców objętości dostępnej przestrzeni. Arystotelesowska doktryna naturalnego ruchu w określonych kierunkach (ku górze, na dół) była podyktowana jego anizotropowym rozumieniem przestrzeni fizycznej, a nie przekonaniem o istnieniu jakiegoś „ślepego finalizmu”. W tym kontekście również idea sferycznej, koncentrycznej struktury świata była niczym innym jak wyrażonym w kategoriach antycznej fizyki dalekim echem dziś opisywanego związku dynamiki i termodynamiki, i wyrażeniem w oparciu o ten związek struktury fizycznej ówcześnie rozumianego Wszechświata. Stąd można powiedzieć, że w fizyce Filozofa nie obowiązuje newtonowskie pojęcie jednorodnej przestrzeni. Właśnie takie geometryczne ujęcie przestrzeni, przy jednoczesnym pomijaniu roli ciepła i zapewnieniu analitycznej przewidywalności ruchów, stworzyło fundament dla analitycznego rachunku newtonowskiej dynamiki i triumfów mechanistycznego rozumienia przyrody ${ }^{17}$.

W tym świetle staje się lepiej zrozumiałe to, że dla Arystotelesa nieodwracalność procesu powstawania nowej formy jest ściśle związana z rolą ciepła. Wyprowadzenie nowej formy z materii jest nałożeniem pewnego limitu ( $\pi \dot{\varepsilon} \rho a \varsigma)$, osiągnięciem wewnętrznego kresu (oủ óc) niestabilnego ruchu materii ${ }^{18}$, co dokonuje się jedynie na końcu danego procesu. W ten właśnie sposób Arystoteles usprawiedliwia swoją definicję formy jako celu materii w jej stawaniu

\footnotetext{
15 Zob. G. Basti, Filosofia dell'uomo, s. 29-36.

16 Zob. Arystoteles, Fizyka, III, 2, 194a 27-29; IV, 7, 479, 482.

17 Zob. G. Basti, Filosofia dell'uomo, s. 36-38.

18 Zob. Arystoteles, Metafizyka, VIII, 2, 1042b 25-27.
} 
się. Podsumowując, można powiedzieć, że przez przyczynę formalno-finalną Arystoteles zasadniczo rozumie dwie rzeczywistości. Po pierwsze, wewnętrzną zasadę uporządkowania, która sprawia, że całość części danego ciała (bytu fizycznego) lub zdania logicznego (byt logiczny) jest różna od zwykłej sumy jej części ${ }^{19}$. Zatem trascendentalna jedność jest czymś co modyfikuje części jednostkowe. Po drugie, stan finalny jest tym, ku czemu dany proces w sposób nieodwracalny jest ukierunkowany. Forma jest tym ze względu na co, coś się

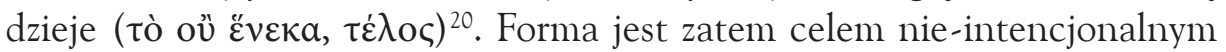
(tj. niezakładającymi istnienia agenta obdarzonego świadomością) pewnego procesu, w którym zachodzi nieodwracalne uporządkowanie biegu przyczyn materialnych i sprawczych w kierunku osiągnięcia mniej lub bardziej stabilnego stanu końcowego. Oznacza to, że do osiągnięcia danego skutku nie wystarczy zbiór przyczyn początkowych, ale trzeba jeszcze zapewnić ich odpowiednie uporządkowanie $(\text { ordo })^{21}$.

\section{Hylemorfizm a biologia}

Chociaż filozofia mechanistyczna na długi czas zdominowała sposób myślenia o przyrodzie i związkach między filozofią a naukami przyrodniczymi, to sama w sobie nauka nie pozwoliła się ujarzmić narzuconym jej schematom pojęciowym. Na skutek gwałtownego rozwoju studiów termodynamicznych u schyłku XIX wieku otworzyła się możliwość stopniowego integrowania nauk biologicznych $z$ dynamicznie rozwijającą się fizyką. W takiej to perspektywie postawione pytanie o specyficzne własności organizmów żywych uzyskało nowe odpowiedzi. Prace Ilya Prigogine'a, laureata Nagrody Nobla z chemii w 1977 roku za wkład w rozwój termodynamiki nierównowagowej procesów nieodwracalnych, a w szczególności za wypracowanie teorii struktur dyssypatywnych, doprowadziły do odejścia od deterministycznego modelowania rzeczywistości.

$19 \quad$ Zob. Arystoteles, Metafizyka, VII, 7, 1041b 10-13.

20 Zob. Arystoteles, Fizyka, III, 2, 194a 27-29.

$21 \quad$ Tak odczytany związek przyczyny sprawczej i finalnej stanowi podstawę tomistycznego określenia przyczyny finalnej jako ratio causalitatis. Bowiem przyczyna sprawcza jest przyczyną przyczyny finalnej quantum ad esse, gdyż sprawia w trakcie zainicjowanego procesu zaistnienie przyczyny formalno-finalnej, tj. to że dany proces staje się realny. Natomiast cel nie jest przyczyną przyczyny sprawczej quantum ad esse, ale w odniesieniu do relacji implikacji przyczynowej. Dzieje się tak dlatego, że takie a nie inne uporządkowanie przyczyn sprawczych sprawia, że na końcu danego procesu zaistnieje określony efekt. W tym sensie przyczyna finalna sprawia, że przyczyna sprawcza jest rzeczywiście efficiens, bo dany cel procesu został osiągnięty w sposób konieczny, ze względu na odpowiednie uporządkowanie przyczyn początkowych (por. Tomasz z Akwinu, De Potentia, q. 5, a. 1). Zatem konieczność relacji przyczynowej przyczyna-efekt zależy od przyczyny formalno-finalnej. 
Prigogine, formułując podstawy teorii chaosu deterministycznego, podkreślił rolę czasu w fizyce, biologii i wprowadził pojęcie struktury dyssypatywnej. Pojęcie to zakłada, że w otwartych systemach, tj. takich, układach termodynamicznych, które wymieniają materię i energię z otoczeniem, dyssypacja może stać się źródłem porządku, kształtowania się pewnych struktur. W konsekwencji istota żywa może być rozumiana jako pewien układ fizyczny, gdzie zachodzą nieustanne procesy chemiczne wymiany materii i bilansu energetycznego. Procesy te zachodzą przede wszystkim w skali mikro i w warunkach dalekich od równowagi termodynamicznej, gdyż organizmy żywe ciągle wymieniają energię (ciepło) z otoczeniem, podlegając działaniu różnych sił i procesom wymiany cząsteczkowej ${ }^{22}$. Mimo to, i to można by określić jako cud życia, odznaczają się one stabilnością układu w warunkach dalekich od równowagi ${ }^{23}$. Co więcej, należy podkreślić, że reakcje chemiczne typowe dla organizmów żywych zachodzą przy temperaturach, patrząc z kosmologicznej perspektywy, niskich. Przyjmując bowiem temperaturę tzw. Big-bangu równą ok. $10^{11}{ }^{\circ} \mathrm{C}(14 \mathrm{mld}$ lat temu), a równocześnie zauważając, że życie rozwija się obecnie w granicach temperatur rzędu $10^{1} \mathrm{C}$ (czyli kosmologicznie patrząc, są to temperatury bliższe wartości zera absolutnego), to rzeczywiście stabilność organizmów żywych musi implikować wysoki stopień ich samoorganizacji, rozumianej jako złożoną strukturę procesów/funkcji życiowych ${ }^{24}$ zróżnicowanych i hierarchicznie

22 Zob. I. Prigogine, I. Stengers, Order out of chaos. Man's new dialogue with nature, Bantam Books 1984, s. 103-209. Por. T. Pabjan, Złożoność i samoorganizacja, [w:] M. Heller, J. Życiński i in., Wszechświat - Maszyna czy myśl, Kraków 2014, s. 452-456.

23 Stan równowagi termodynamicznej dla organizmu żywego oznaczałby jego śmierć, tzn. stan jego równowagi termicznej z otoczeniem (zimne ciało zmarłego człowieka), czyli stan niestabilności, stopniowej dekompozycji. Dokładniej należałoby powiedzieć, że organizm wraz z jego środowiskiem, z którego dany organizm dzięki procesom metabolizmu pobiera konieczną do życia energię, stanowią system w równowadze termodynamicznej. Pobieranie energii $z$ otoczenia nie tłumaczy życia jako takiego, lecz wyraża jedynie warunek konieczny dla jego zaistnienia. Sekret procesów życiowych tkwi bowiem w przekształceniu pobranej z otoczenia energii i przekształceniu jej w informację, strukturę podtrzymującą wewnętrzną organizację organizmu, która przeciwstawia się procesowi wzrostu entropii, charakteryzującego systemy w równowadze termodynamicznej.

24 Dana funkcja, proces może być rozumiana w terminach arystotelesowsko-tomistycznych jako działanie szczególnego bytu, czy to substancji (np. pewien organizm żywy) czy części substancji (np. pewien organ). Dany proces może być definiowany w postaci matematycznej jako funkcja wiążąca dwie lub więcej wartości zmiennych. W ten sposób zaistnienie danego procesu życiowego w obrębie organizmu lub jakiejś jego części, będzie reprezentowane, na mocy sformułowanych matematycznie zależności, za pomocą rachunku określonych wartości wyjścia (output) danej funkcji zależnych od określonych wartości wejścia (input) w ramach danej funkcji, która jest „wcielona” w biologicznym funkcjonowaniu danego organizmu. Właśnie dlatego mówi się w biologii o funkcjach czy procesach życiowych. 
powiązanych, ukierunkowanych na zachowanie przy życiu organizmu i jego reprodukcję.

W kontekście procesów życiowych samoorganizacja, matematycznie modelowana we współczesnych teoriach biologicznych, musi być rozumiana jako nieliniowa/nieredukowalna złożoność powiązana z różnymi poziomami organizacji materii. Organizmy żywe odznaczają się bowiem hierarchicznym uporządkowaniem funkcji, co oznacza, że niektóre części wyższej organizacji, kontrolują funkcjonowanie tych na niższym poziomie, w taki sposób, że wszystkie części (ôpyavov) stają się organami pewnego organizmu, który jako całość reguluje funkcje poszczególnych swoich organów, te regulują pracę komórek; komórki zaś procesy wymiany molekularnej. Jednak równocześnie od najbardziej podstawowych procesów w kierunku bardziej złożonych przebiegają procesy zwrotnego oddziaływania. Nie wystarcza bowiem, aby organy bardziej złożone „używały” te należące do niższego poziomu organizacji. Wyższa struktura reguluje, stymuluje, a nawet i blokuje działania tej niższej w momencie, gdy ta druga osiągnie stan, cel determinowany przez tę wyższą. Tak więc, aby kontrolny organ wyższego porządku „zdał sobie” sprawę z procesów zachodzących na niższym poziomie, konieczne jest, aby niższy poziom przekazywał sygnał do wyższego, co sprawia że funkcja biologiczna nabywa charakteru tzw. feed back loop ${ }^{25}$. Ten cyrkularny charakter funkcji życiowych może być określony

25 W odróżnieniu od redukcyjnych ujęć mechanistycznych (organizm jako maszyna) opartych na pojęciu machiny inercjalnej (kartezjańska automa), czyli zasadzie bezwładności i układzie oddziaływania typu akcja-reakcja, sugerowane tutaj rozumienie procesów biologicznych związane jest z pojęciem finalizmu, matematycznie ujętym w postaci tzw. feed back loop. To ostatnie bowiem zakłada istnienie wewnętrznego systemu, egzekwowanego przez pewien podsystem układu (kontroler), kontrolującego funkcjonowanie innego podsystemu (efektor). Pewien rodzaj czujnika umieszczonego na wyjściu podsystemu efektora (output) zwrotnie oddziałuje na podsystem kontrolny, formułując pomiar wyjściowej wartości (output). Zwrotne oddziaływanie nie jest zwykłą reakcją, co mogłoby sugerować ujmowanie tego oddziaływania w kluczu III zasady dynamiki Newtona, lecz implikuje istotne rozróżnienie pomiędzy przesyłem energii a informacji. Rozróżnienie powszechnie powielane w naukach kognitywnych i informatycznych w postaci dystynkcji pomiędzy hardware a software danego systemu. Dopóki więc wartość wyjściowa systemu nie będzie zgodna z wartością zaprogramowaną, dopóty działanie podsystemów będzie kontynuowane i działanie na wejściu systemu będzie się powtarzać (input). Tak opisany system charakteryzuje się globalnymi właściwościami liniowymi, gdyż funkcja matematyczna sterująca układem oblicza odległość między wartością do osiągnięcia, z góry określoną, a wartością output. Tymczasem nie jest możliwe modelowanie funkcji organizmów żywych za pomocą przekształceń liniowych. To właśnie nieredukowalna nieliniowość procesów biologicznych sprawia, że funkcje regulujące zachowanie organizmu mogą się zmieniać w zależności od środowiska wewnętrznego lub zewnętrznego danego organizmu. Oznacza to więc, że organizmy żywe, zarówno na poziomie wegetatywnym jak i kognitywnym, nie są jedynie maszynami manipulującymi danymi, które w z góry zdefiniowany sposób zostały w nich „implementowane”, ale mają zdolność generowania informacji w oparciu 
jako wewnętrzny finalizm, który w przypadku wszystkich organizmów żywych determinuję naturę i zachowanie danego organizmu. W przypadku człowieka, co wyraźnie podkreśla filozofia arystotelesowsko-tomistyczna, zdolność autodeterminacji (samoorganizacji) jest całkowita, gdyż człowiek odznacza się świadomością celów swojego działania i wolnością ich modyfikowania, wyboru. W rzeczywistości cel działań organizmów żywych, świadomych i nieświadomych (w odróżnieniu od ogólnie wcześniej analizowanej przyczyny finalnej), staje się przynajmniej w pewnym zakresie wewnętrzny, immanentny wobec funkcjonowania istot żywych dzięki hierarchicznej i autoregulacyjnej strukturze procesów biologicznych. W odróżnieniu więc od zwykłego przechodniego (tranzytywnego) oddziaływania fizycznego (np. uderzenie jednej bili w drugą, co powoduje przekazanie ruchu tej drugiej, zgodnie $z$ teorią zderzeń mechanicznych), w przypadku działań immanentnych mamy do czynienia z globalną formą samoorganizacji pojedynczych oddziaływań tranzytywnych czy wcześniej wspomnianych przemian fizyczno-chemicznych w obrębie materialnych części organów. Do takich działań należą więc wszelkie funkcje życiowe (np. oddychanie, odżywianie, widzenie, chodzenie), które nie są niczym innym niż niezwykle złożonymi strukturami organizującymi miriady mikroprocesów przechodnich. Poczynając więc od najniższego, wegetatywnego poziomu, przykładem działania immanentnego będą wszelkie procesy fizyczno-chemiczne na poziomie czy to pojedynczych komórek, czy złożonych organizmów wielokomórkowych. $\mathrm{Na}$ kolejnym poziomie, autoregulacja będzie formą globalnej organizacji działań przechodnich pomiędzy różnymi organami zbudowanymi z tkanek. Wreszcie na poziomie sensomotorycznym, np. wzajemne „powiązanie” kończyn i mózgu w trakcie wykonywanego pod wpływem impulsów nerwowych ruchu, wyraźnie widać immanentny charakter funkcji biologicznych. W przypadku człowieka pojawia się jeszcze ostatni poziom, działanie intelektualne, gdzie mamy do czynienia z immanentnym działaniem bezpośrednim (reflexio), które w odróżnieniu od innych funkcji organicznych dokonuje się bez pośrednictwa narządów, chociaż w pewnym zakresie jest uzależnione od procesów materialnych ${ }^{26}$.

Podsumowując, wszystkie działania immanentne, jako formy złożonej organizacji działań tranzytywnych (procesy fizyczno-chemiczne) poszczególnych części organizmu, domagają się włączenia w szerszą strukturę, która je zawiera i której stanowią przejaw. Ta forma, która gwarantuje jedność wszystkich części (organów) i wszystkich funkcji danej istoty żywej, biologicznie ujmowanej jako organizm, a metafizycznie jako substancja, to forma substancjalna danego ciała,

o działanie autoregulacyjne, gdyż to ostatnie zakłada aktywne oddziaływanie organizmu z jego własnym środowiskiem wewnętrznym jak i typową dla niego niszą ekologiczną. Por. J. Bremer, Wprowadzenie do filozofii umystu, s. 45-50; G. Basti, Filosofia dell'uomo, s. 143-154. 
dusza. Jest ona „pierwszym aktem ciała naturalnego, które posiada w możności życie, czyli ciała obdarzonego organami”27. Zatem poszczególne funkcje biologiczne (działania immanentne) są aktami drugimi organizmu. Wydaje się zatem, że hylemorficzne rozumienie organizmów żywych stwarza odpowiednią teoretyczną płaszczyznę dla mówienia o finalizmie biologicznych procesów ${ }^{28}$. Unika bowiem popadnięcia w błędy redukcyjnie ujętego funkcjonalizmu (fragmentacja zasady jedności, organizm jako agregat wyspecjalizowanych części) jak i nie wikła się w wewnętrzne niejasności teorii witalistycznych (ryzyko dualizmu substancjalnego ${ }^{29}$.

\section{Hylemorfizm a fizyka}

Potwierdzony doświadczalnie Model Standardowy, czyli teoria fizyki dotycząca cząstek elementarnych, jak coraz częściej się wskazuje, nie jest w pełni satysfakcjonujący z teoretycznego punktu widzenia. Nagroda Nobla z fizyki z 2015 roku za badanie problemu neutrin, cząstek elementarnych mających zerowy ładunek elektryczny i słabo oddziałujących z materią, i wykazanie, że są one obdarzone masą, potwierdza zasadność dyskusji nad ograniczeniami Modelu Standardowego, wyjaśniającego z kosmologicznego punktu widzenia jedynie zwykłą materię, której wkład do parametru gęstości jest na poziomie jedynie $4,9 \%^{30}$. Wydaje się, że przy ciągłym braku osiągnięcia satysfakcjonujących rezultatów w zakresie tzw. skwantowania grawitacji, dobrym kandydatem dla dalszych badań w fizyce cząstek elementarnych może być kwantowa teoria pola (QFT, quantum field theory), stosowana nieprzerwanie w fizyce cząstek elementarnych od prawie 100 lat. W odróżnieniu od mechanistycznej wizji natury ${ }^{31}$, w QFT każda cząstka, czy to fermion czy bozon, rozpatrywana jest

27 Zob. Arystoteles, De Anima, II, 1, 412a 35.

28 Niezależnie od tego, czy ktoś jest, czy nie przekonany o wewnętrznym finalizmie procesów to właśnie współczesna bionika, nazywana również biomimetyką, badając budowę i zasady działania organizmów, symuluje ich funkcjonowanie i następnie próbuje konstruować urządzenia techniczne na wzór organizmu oraz stara się wykorzystywać procesy sterujące

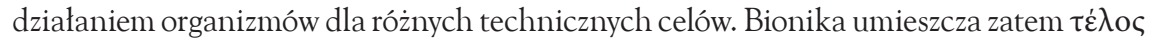
w przyrodzie. Por. H.-D. Mutschler, Wprowadzenie do filozofii przyrody, tłum. J. Bremer, Kraków 2005, s. 134-139.

Ibidem, s. 59-61.

30 Por. T. Pabjan, Niedomknięty bilans wszechświata, Kraków 2016, s. 7-13, 167-174.

31 W przypadku ontologii Newtona taka wizja zakłada istnienie wyizolowanych ciał oddziałujących w mechanicznej próżni. Również w przypadku mechaniki kwantowej (QM), zarówno w zakresie studium fundamentalnych oddziaływań w ramach elektrodynamiki kwantowej (QED) jak i chromodynamiki kwantowej (QCD), zakłada się, z ontologicznego punktu widzenia, istnienie mechanistycznego schematu w postaci rozróżnienia cząstek 
jako kwant odpowiedniego pola. Ponadto QFT zakłada istnienie, nie próżni mechanicznej postulowanej w przypadku ontologii mechanistycznej, lecz próżni kwantowej (QV, quantum vacuum) rozumianej jako stan najniższej energii, ujmowany w sformułowaniu dynamiki równoczasowej jako ocean bez przerwy pojawiających się i znikających par cząstek ${ }^{32}$. Z fenomenologicznego punktu widzenia QV jawi się jako korelat arystotelesowskiej materii pierwszej. To właśnie zachodzące w kwantowej próżni ciągłe procesy kreacji i anihilacji cząstek w „operacyjny sposób” wyrażają fundamentalną, będącą implikacją szczególnej teorii względności, relację równoważności energii i masy ${ }^{33}$.

Niemożliwość osiągnięcia przez dany system fizyczny stanu zera absolutnego implikuje, że każdy system na swoim podstawowym poziomie kwantowym jest wewnętrznie otwarty na fluktuacje próżni kwantowej. W związku z tym strukturalna stabilność systemu zależy od dynamicznego, przyczynowo determinowanego bilansu energetycznego z QV. Kinematyka, czyli prawa ruchu cząstek, zależą zatem od dynamiki, przyczynowego oddziaływania sił. Każde złamanie symetrii oznacza więc lokalny podział QV na parę system i jego termiczny korelat (thermal field). Przekazanie więc energii zakłada komunikację formy, gdyż każda wymiana kwantów energii jest związana z zaistnieniem koherencji faz w ramach oscylacji pól. Kwanty oscylacji, bozony Nambu-Goldstone to prawdziwe cząstki, obserwowane za pomocą tych samych technik co inne cząstki kwantowe, które jednak nie istnieją poza systemami, które porządkują ${ }^{34}$. Wszystkie te bozony istnieją tak długo jak trwa dany stan materii. Używając terminologii tomistycznej można by powiedzieć, że przyczynowość sprawcza na poziomie oddziaływań fizycznych jest communicatio materiae (energia) oraz

od sił oddziaływania. Tak więc intuicyjnie można opisać ten model w kategorii cząstek, które wymieniają między sobą kwanty sił.

Pojęcie elektrodynamicznej próżni kwantowej rozumianej jako dynamiczny substrat materialny każdego systemu fizycznego wynika z III zasady termodynamiki, która określa, że na żadnym poziomie materii nie jest możliwe osiągnięcie temperatury zera bezwzględnego. Innymi słowy oznacza to, że w naturze wszystko się porusza, wibruje na najbardziej podstawowym poziomie materii, a zatem każdemu ciału fizycznemu można przypisać pole sił wzajemnego oddziaływania.

33 International Research Area on Foundations of Science, IRAFS Newsletter 1 (2016), s. 7-10, http://www.irafs.org/materials/2016_nl1_eng.pdf (dostęp: 26 listopada 2017).

Zob. J. Goldstone, A. Salam, S. Weinberg, Broken Symmetries, w Physical Review 127, 965, published 1 August 1962 (doi.org/10.1103/PhysRev.127.965); C. Itzykson, J. Zuber, Quantum field theory, New York 1980; H. Umezawa, Advanced field theory: micro, macro and thermal concepts, New York 1993. W przypadku kryształów nazywa się je fononami; w ferromagnetykach - magnonami; a w materii ożywionej mówi się o występowaniu kwantów fal dipolowych - DWQ (dipole wave quanta). QFT daje więc teoretyczne podstawy do opisu mikroskopowych zjawisk kwantowych, które uwidaczniają się w skali makroskopowej: kryształy, nadprzewodniki, ferromagnetyki, procesy biochemiczne. 
impressio similitudinis (forma), a więc jest co do swej struktury hylemorficzna ${ }^{35}$. Pojęcie próżni kwantowej (QV), proces łamania symetrii (spontaneous symmetry breakdown) oraz rozróżnienie pomiędzy bozonami gauge a bozonami Goldstone'a, stwarzałoby więc podstawę do ujmowania ciał fizycznych (zbudowanych $z$ kwarków i elektronów, wraz z gluonami i fotonami) jako lokalnych, koherentnych oscylacji cząsteczek (phase coherence domains). Lokalna koherencja oddziaływań zdaje się być fenomenologicznym korelatem pojęcia formy, która organizuje materię (masę, energię) w czasie rzeczywistym ${ }^{36}$.

Powyższe idee fizyczne również znajdują rozwinięcie i aplikację do badania struktur dyssypatywnych, a więc systemów biologicznych, a w tym badań nad mózgiem ${ }^{37}$. Wielką zaletą tego podejścia jest próba łączenia wyników badań w zakresie biologii molekularnej (metody statystyczne i probabilistyczne dotyczące poziomu mikroskopowego) z biologicznymi procesami samoorganizacji dokonującymi się na poziomie mezo- i makroskopowym, o których już wcześniej wspomniano. W konsekwencji takie podejście daje teoretyczną podstawę do bardziej precyzyjnego definiowania pojęcia emergencji, stwarza matematyczne podstawy do ujęcia teoretycznych założeń teorii I. Prigogine'a, której brakowało matematycznego ufundowania ${ }^{38}$ oraz może stanowić dobry argument przeciw radykalnie materialistycznym próbom interpretacji natury. Aplikacja pewnych elementów kwantowej teorii pola w kontekście badań nad żywymi organizmami opiera się na trzech zasadniczych obserwacjach. Po pierwsze, systemy biologiczne, jak już zostało wspomniane, są systemami otwartymi (strukturami dyssypatywnymi), które dokonują ciągłej wymiany materii i energii z otoczeniem. Po drugie, wszystkie makromolekuły (białka) budujące żyjące organizmy stają się biologicznie aktywne jedynie w wodzie. Po trzecie, ścisłe powiązanie wody i ożywionej materii opiera się na fakcie, iż cząsteczki

35 Zob. G. Basti, L'idea di scienza di Maritain tra passato e futuro, s. 126-130.

36 Zob. G. Basti, Lontologia formale del «realismo naturale», cosmologia evolutiva e partecipazione dell'essere, s. 244-262.

37 Zob. M. Bischof, Sincronizzazione e coerenza come prinicpio organizzativo nell'organismo, nell'interazione e nelle coscienza (Synchronization and coherence as an organizing principle in the organism, social interaction and consciousness), [w:] La medicina biologica 2010/4, s. 35-43. To że w tym kontekście mówi się o QFT systemów dyssypatywnych można w obrazowy sposób wyjaśnić, uwzględniając, że ludzki mózg stanowiący 2\% masy ludzkiego ciała, rozprasza aż ok. 20/25\% energii spoczynkowej ciała. Dlatego W. Freeman podkreśla, że dynamika ludzkiego mózgu to potężny rezerwuar energii. Por. A. Capolupo, W. J. Freeman, G. Vitiello, Dissipation of dark energy by cortex in knowledge retrieval, "Physics of life reviews", 10 (1), 2013, s. 85-94 (doi: 10.1016/j.plrev.2013.01.001).

38 Por. I. Prigogine, Le leggi del caos, Roma - Bari 2008; E. Del Giudice, R. Pulselli, E. Tiezzi, Thermodynamics of irreversible processes and quantum field theory: an interplay for understanding of ecosystem dynamics, "Ecological Modelling" 220, 2009, s. 1874-1879. 
wody tak jak i makromolekuły ożywionej materii są obdarzone elektrycznym momentem dipolowym, tj. z powodu ich asymetrycznej struktury stanowią spolaryzowane molekuły ${ }^{39}$.

Ograniczenie się w badaniach nad organizmami żywymi do statystycznych i probabilistycznych metod wyrażających molekularną kinetykę jest w stanie dobrze modelować zjawiska na poziomie mikroskopowym. Dlatego właśnie „QFT dyssypacyjna” wydaje się, że mogłaby stanowić brakujący element w biochemii i morfogenezie biologicznej ${ }^{40}$. Zgodnie $z$ jej teoretycznymi założeniami, każda struktura/funkcja biologiczna to porządek czasowo-przestrzenny pewnych reakcji chemicznych. Ponieważ siły chemiczne (np. siły Van der Waalsa) działają tylko na krótkie odległości, pojawia się zasadnicze pytanie o to, co organizuje ruch molekularny dążący do umieszczenia danej cząsteczki blisko obiektu, na który ma ona oddziaływać. Jedyny sposób efektywnego „skanalizowania" molekuł, gdzie każda z nich oscyluje z charakterystycznymi dla siebie częstotliwościami, polega na poddaniu ich pod działanie pól elektromagnetycznych, oscylujących również według określonych częstotliwości. W takim kontekście materia ożywiona jest ujmowana jako zbiór dipolów elektrycznych o złamanej symetrii rotacji (ze względu na obecność wody wraz z jej dipolowymi właściwościami), a każda funkcja biologiczna składa się z uporządkowanej sekwencji reakcji chemicznych. Zasada dynamicznego uporządkowania reakcji sugerowana przez QFT, intuicyjnie może być wyobrażona jako rezonujące, rozchodzące się pole akustyczne, które sprawia, że nastrojone odpowiednio instrumenty zaczynają w zakresie danej częstotliwości być pobudzone do drgań. W wyniku reakcji zostaje osiągnięty nowy stabilny stan wiązań chemicznych. Tak opisany dynamiczny mechanizm stosowany jest do wyjaśnienia powstawania i niszczenia struktury cytoszkieletu, tj. sieci włóknistych struktur białkowych w komórce eukariotycznej stanowiących jej elastyczny szkielet oraz możliwości propagacji w ramach jego struktury fal solitonowych, stanowiących rodzaj niedyssypatywnego transportu energii wewnątrz systemu. W przeciwnym bowiem razie transportowana energia nie mogłaby być wykorzystana dla funkcji biochemicznych, a co więcej jej dyssypacja wewnątrz systemu spowodowałaby niszczycielskie skutki dla funkcjonowania systemu ${ }^{41}$. W metaforyczny sposób

39 Zob. E. Del Giudice, A. Tedeschi, La dinamica dell'essere vivente come riflesso della dinamica dell'acqua (The dynamics of the living being as the reflection of water dynamics), "La medicina biologica" 2010/4, s. 21-27.

40 Zob. G. Vitiello, Stati coerenti e domini coerenti nella fisica della materia vivente (Coherent states and coherent domains in the physics of the living matter), "La medicina biologica" 2010/4, s. 13-19.

41 Zob. G. Vitiello, Stati coerenti e domini coerenti nella fisica della materia vivente (Coherent states and coherent domains in the physics of the living matter), "La medicina biologica", 
można więc powiedzieć, że teoretyczna struktura QFT jest operacyjnym ujęciem „melodii” czy „symfonii życia”, tj. teoretycznym wyrażeniem swoistego „zestrojenia” oddziaływań materialnych w ramach dynamicznego mechanizmu funkcjonowania uporządkowanych struktur biologicznych.

Teoria QFT znajduje w ostatnich latach również swoją aplikację do badań funkcjonowania ludzkiego mózgu. Walter Freeman i jego grupa badawcza działająca przy Uniwersytecie Kalifornijskim w Berkeley, nie tylko podziela teoretyczne założenia QFT ${ }^{42}$, ale dokonała wielu obserwacji, pomiarów i prób modelowania fenomenu aktywności mózgu u różnych ssaków, w tym u człowieka, w czasie wykonywania przez nich różnych intencjonalnych czynności. Stosowane przez tych badaczy zaawansowane techniki obrazowania podstawowej aktywności mózgu (background activity) w odniesieniu do synaptycznej aktywności neuronów (neurofizjologia) zaowocowały znaczącymi rezultatami. Przede wszystkim udało im się wskazać obecność spójnych wzorców oscylacji fal mózgowych, które manifestowały phase locking zarówno w modulacji amplitudy (AM) i modulacji częstotliwości (FM) ${ }^{43}$. Oznacza to, że badana przez nich zasadnicza aktywność mózgu (background) była modulowana w częstotliwości i/lub amplitudzie na skutek aktywnego, intencjonalnego zaangażowania mózgu osobnika ze względu na jego stosunek do środowiska. Ponadto udało im się określić mózgowe „pakiety falowe” (wave packets), czyli zjawiska rezonansu, które w krótkim czasie mogą obejmować całą półkulę mózgową u królików i kotów lub regiony o długości liniowej równej 19 cm w ludzkim mózgu, powodując ich silne skorelowanie. Oznacza to eksperymentalne potwierdzenie istnienia zjawisk oscylacji zsynchronizowanej w dużej skali dla neuronów mózgu ludzkiego, zarówno w stanie spoczynku jak i zaangażowanych w zadaniach motorycznych.

2010/4, s. 16-17; E. Del Giudice, S. Doglia, M. Milani, G. Vitiello, A quantum field theoretical approach to the collective behavior of biological systems, Nucl. Phys. B251 (FS 13), 1985, s. 375-400; E. Del Giudice, S. Doglia, M. Milani, G. Vitiello, Electromagnetic field and spontaneous symmetry breakdown in biological matter, Nucl. Phys. B275 (FS 17), 1986, s. 185-199.

42 Zob. W. J. Freeman, G. Vitiello, Nonlinear brain dynamics as macroscopic manifestation of underlying many-body field dynamics, "Physics of Life Reviews", 3 (2), 2006, s. 93-118; idem, Dissipation and spontaneous symmetry breaking in brain dynamics, "Journal of Physics A: Mathematical and Theoretical" 41 (30), 2008, 304042.

43 Zob. G. Vitiello, Coherent states, fractals and brain waves, "New Mathematics and Natural Computing" 5 (1), 2009, s. 245-264. 


\section{Otwarte perspektywy}

Wydaje się, że bujny rozwój studiów nad fenomenem życia oraz przemiany w zakresie teorii cząstek elementarnych mogą stanowić okazję do zbliżenia myśli arystotelesowsko-tomistycznej z tym, co oferuje aktualny rozwój science. $\mathrm{Z}$ jednej strony w tym dialogu istnieje ryzyko konkordyzmu, a $z$ drugiej wydaje się, że filozofia nie może pozostać obojętna wobec pytań stawianych w kontekście nauk przyrodniczych i używanych przez nie pojęć, które zazwyczaj są dobrze znane różnym tradycjom filozoficznym.

Z powyżej wzmiankowanych, w zakresie biologii i fizyki, przyrodniczych teorii wyłania się obraz nauki, która oddala się od nowożytnego mariażu z ontologią mechanistyczną.

Złożoność strukturalna i funkcjonalna organizmów, a przede wszystkim finalizm zjawisk biologicznych stanowią nieprzezwyciężoną trudność, impas nie do rozwiązania, który uniemożliwia akceptację mechanistycznej interpretacji życia. (...) Wszystkie próby stworzenia mechanistycznej interpretacji świata kończyly się porażką ze względu na następujące fakty: a) nieadekwatność praw fizyki do wyjaśnienia finalizmu biologicznego, b) nadmierną surowość schematów fizycznych w stosunku do niezwykle subtelnych i złożonych zjawisk biologicznych, c) brak zrozumienia ze strony „redukcjonizmu”, że na każdym poziomie integracji zachodzącej w układach biologicznych pojawiają się nowe cechy, które potrzebują nowych zasad wyjaśnienia, nieznanych (i niepotrzebnych) w fizyce ${ }^{44}$.

Dlatego właśnie dzisiejsza fizyka już nie tylko bada materię (masa/energia: fizyczne wielkości fizyczne), ale także aspekty strukturalne (formę, informację, samoorganizację: fizyczne wielkości niematerialne), co staje się widoczne w kontekście następującego zbliżenia fizyki i biologii w badaniach fenomenu życia. W miejsce dawniej dominujących redukcyjnych interpretacji natury, powraca więc ontologia dualna, podkreślająca wspólistnienie dwóch pryncypiów: formy (informacji, struktury, koherencji) i materii (masy/energii). W kontekście wyżej przeprowadzonych analiz, intuicyjnie można więc określić formę jako relację uporządkowania elementów, które mogłyby znajdować się w innym ułożeniu, determinującą całość systemu i niedającą się zredukować do własności poszczególnych podsystemów. To właśnie w filozofii klasycznej wewnętrzny związek materii (potencji) z formą (aktem) jest czymś fundamentalnym dla metafizycznego rozumienia rzeczywistości.

Z powyżej zarysowanych zagadnień również wynikają pewne implikacje dla rozumienia statusu ontologicznego osoby. Osoba to żyjące ludzkie ciało, psychofizyczna jedność formy i materii w ciągłej relacji wymiany materii i informacji $z$ otoczeniem. Jako wysoce ustrukturyzowany organizm biologiczny, osoba to

44 G. Montalenti, From Aristotle to Democritus via Darwin, [w:] Studies in the Philosophy of Biology, F.J. Ayala, T. Dobzhansky (red.), London 1974, s. 16-17. 
indywiduum zdolne do autodeterminacji, ale w odróżnieniu od pozostałych organizmów żywych, jest zdolna na wszystkich trzech poziomach samoorganizacji, tj. na poziomie operacji wegetatywnych (wzrost, metabolizm, rozmnażanie), gdzie forma i cel tych operacji są genetycznie określone; na poziomie działań sensomotorycznych, gdzie biologiczne instynkty są genetycznie zdeterminowane; i wreszcie na poziomie działań intelektualnych i wolnych charakteryzujących się możliwością wyboru celów. Na tym ostatnim poziomie mają znaczenie wpływy kulturowe („ludzka nisza ekologiczna”, którą jest społeczeństwo), ale również ujawnia się zdolność wpływania osoby na uwarunkowania kulturowe. Tożsamość osoby rozgrywa się więc na poziomie jej nieredukowalnej osobowości (incommunicabilitas), jednostkowej niepowtarzalności, która znajduje swój szczególny wyraz w działaniu ludzkiego intelektu. Śmierć człowieka to dekompozycja materialna, która następuje na skutek utracenia unifikującej zasady jedności, formy/duszy stanowiącej pierwszy akt ciała materialnego. Tak zarysowane implikacje domagają się z pewnością bardziej systematycznej analizy zarówno ontologicznego języka zakładanego w ramach omawianych zagadnień przyrodniczych jak i struktury formalnej metafizyki klasycznej. Ze względu na rozwój ontologii formalnej wydaje się, że takie próby zostały już podjęte i dają nadzieję na bardziej systematyczno-formalne ujęcie omawianych związków ${ }^{45}$.

Również aplikacja teoretycznych założeń QFT do obrazowania procesów mózgowych i wyjaśniania dynamiki funkcjonowania mózgu, wydaje się sprzyjać bardziej systematycznemu ujęciu kwestii intencjonalności (enacted, extended mind) oraz intersubiektywności (embedded mind) ludzkiego poznania. Wyniki, przeprowadzonych przez W. Freemana i jego wspólpracowników, badań wskazują na to, że rozpoznanie ,intencjonalne” bodźca ze strony mózgu odpowiada momentowi (rzędu dziesiątych części sekundy) zaistnienia „domeny koherencji” oscylacji pól neuronalnych w rozszerzonym obszarze mózgu. Takie podejście do badania mózgu stanowi więc konkurencyjne ujęcie wobec różnych materialistycznych, koneksjonistycznych i modularnych teorii umysłu ${ }^{46}$. Dominujące w omawianych teoriach dynamiczne ujęcie procesów, które matematycznie modeluje przyczynowe oddziaływanie badanych obiektów, sprzyja odnowionej dyskusji nad problemem przyczynowości i relacją teorii przyrodniczych do opisywanych przez nie zjawisk. Z ontologicznego punktu widzenia żadna $z$ teorii przyrodniczych nie jest w stanie wyjaśnić zaistnienia substratu materialnego,

45 Por. G. Basti, L'ontologia formale del «realismo naturale», cosmologia evolutiva e partecipazione dell'essere,"Divus Thomas" 117-2 (2014), s. 229-334; idem, Ontologia formale: Tommaso Aquino ed Edith Stein, [w:] A. Ales Bello, F. Alfieri, M. Shahid (red.), Edith Stein - Hedwig Conrad-Martius - Gerda Walther, Fenomenologia della Persona, della Vita e della Comunità, Bari 2011.

46 Por. J. Bremer, Wprowadzenie do filozofii umystu, Kraków 2010, s. 111-121, 136-146. 
nawet tego opisywanego jako kwantowa próżnia, odznaczającego się brakiem wewnętrznego uporządkowania, a zatem do zakresu teorii przyrodniczych nie należy dyskusja na temat ewentualnego creatio ex nihilo. Fizyka, czy biologia nie mogą podawać przyrodniczych wyjaśnień metafizycznych lub teologicznych pojęć, pretendując do ich całkowitego wyjaśnienia. Zatem pytanie o Przyczynę Pierwszą wszystkich procesów naturalnych nie zostaje w żadnym stopniu unieważnione.

Dyskusja nad statusem ontologicznym człowieka, co znajduje wyraz w szeroko dyskutowanym obecnie problemie mind-body, stanowi charakterystyczne dziedzictwo myśli europejskiej. W dzisiejszej dyskusji nad ontologią człowieka nie widać jednoznacznej, powszechnie akceptowanej możliwości rozstrzygnięcia sporu między paradygmatem redukcjonistycznym, dążącym do prostoty i poszukującym tego, co "fundamentalne” a tym antyredukcjonistycznym, skoncentrowanym na samoorganizacji i wzrastającej złożoności ${ }^{47}$. Czy zatem brak takiej odpowiedzi dziś może skłaniać do pesymizmu poznawczego? Rémi Brague, w swoim eseju na temat tego, co stanowi o kulturze Europy, parafrazując słowa znanego filozofa - Ortegi y Gasseta, wyraził przekonanie, że „zawartością Europy jest właśnie to, że jest pojemnikiem, że jest otwarta na powszechność"48. Zatem zdaje się właśnie specyficznym wyrazem dziedzictwa myśli europejskiej ponowne stawianie ważkiego pytania o status ontologiczny człowieka i poszukiwanie nowej syntezy, która w zrozumiały dla współczesnego człowieka sposób, wyrazi klasyczne intuicje filozoficzne.

Podziękowanie. Autor pragnie wyrazić wdzięczność Arkadiuszowi Trawińskiemu i Joannie Jankowskiej za przeczytanie manuskryptu i zasugerowanie cennych uwag. Ewentualne błędy i niekonsekwencje pozostają z winy autora.

47 Zob. T. Pabjan, Złożoność i samoorganizacja, [w:] M. Heller, J. Życiński i in., Wszechświat -Maszyna czy myśl, s. 465-467. M. Heller twierdzi, że po upadku neopozytywizmu fizykalizm, głoszący, że wszystko da się zredukować do fizyki, najczęściej pojawia się w pismach biologów. W taki oto sposób zredukowanie biologii do praw fizycznych często jest uznawane przez biologów za pełne zrozumienie badanych procesów. Jednak dzisiejsza fizyka, która poszukuje fundamentalnych praw przyrody, obecnie w dużej części sprowadza się do nauki czysto formalnej, jaką jest matematyka. Zdaje się więc, że zarówno niedawne przemiany w filozofii matematyki (tj. niepowodzenie programu Hilberta) i w samej matematyce (jak bujny rozwój teorii kategorii) stwarzają nadzieję, że nowa racjonalność matematyki również może rzutować na nasze nowe rozumienie przyrody. Por. M. Heller, Otwarte perspektywy świata myśli i świata przyrody, [w:] M. Heller, J. Życiński i in., Wszechświat - Maszyna czy myśl, s. 469-474.

R. Brague, Europa, droga rzymska, tłum. W. Dłuski, Warszawa 2012, s. 167. 
Słowa kluczowe: dusza ludzka, hylemorfizm, ontologia, antropologia, neuronauka, kwantowa teoria pola

\section{Bibliografia:}

1. Arystoteles, Fizyka, tłum. K. Leśniak, [w:] Arystoteles, Dzieła Wszystkie, t. 2, Warszawa 1990.

2. Arystoteles, Metafizyka, tłum. K. Leśniak, [w:] Arystoteles, Dzieła Wszystkie, t. 2, Warszawa 1990.

3. Arystoteles, O Duszy, tłum. P. Siwek, [w:] Arystoteles, Dzieła wszystkie, t. 3. Warszawa 1992.

4. Audi R., Naturalism as a Philosophical and Scientific Framework. A Critical Perspective, [w:] Between Philosophy and Science, M. Heller, B. Brożek, Ł. Kurek (red.). Kraków 2013.

5. Basti G., Perrone A.L, Le radici forti del pensiero debole. Dalla metafisica, alla matematica, al calcolo, Padova - Roma 1995.

6. Basti G., Filosofia dell'uomo, Roma 2008.

7. Basti G, Ontologia formale: Tommaso Aquino ed Edith Stein, [w:] Edith Stein - Hedwig Conrad-Martius - Gerda Walther, Fenomenologia della Persona, della Vita e della Comunità, A. Ales Bello, F. Alfieri, M. Shahid (red.), Bari 2011.

8. Basti G., L'ontologia formale del «realismo naturale», cosmologia evolutiva e partecipazione dell'essere, "Divus Thomas" 117-2 (2014), s. 229-333.

9. Basti G., Lidea di scienza di Maritain tra passato e futuro, "Aquinas" LVIII (2015), s. $117-165$.

10. Bischof M., Sincronizzazione e coerenza come prinicpio organizzativo nell'organismo, nell'interazione e nelle coscienza (Synchronization and coherence as an organizing principle in the organism, social interaction and consciousness), "La medicina biologica" 2010/4: 35-43.

11. Brague R., Europa, droga rzymska, tłum. W. Dłuski, Warszawa 2012.

12. Bremer, J., Wprowadzenie do filozofii umystu. Kraków 2010.

13. Capolupo A., Freeman W.J., Vitiello G, Dissipation of dark energy by cortex in knowledge retrieval, "Physics of life reviews", 201310 (1): 85-94 (doi: 10.1016/j. plrev.2013.01.001).

14. Del Giudice E., Doglia S., Milani M., Vitiello G., A quantum field theoretical approach to the collective behaviour of biological systems, "Nucl. Phys." 1985 B251 (FS 13): 375-400.

15. Del Giudice E., Doglia S., Milani M., Vitiello G., Electromagnetic field and spontaneous symmetry breakdown in biological matter, "Nucl. Phys." 1986 B275 (FS 17): 185-199.

16. Del Giudice E., Pulselli R., Tiezzi E, Thermodynamics of irreversible processes and quantum field theory: an interplay for understanding of ecosystem dynamics, "Ecological Modelling" 2009, 220: 1874-1879.

17. Del Giudice E., Tedeschi A., La dinamica dell'essere vivente come riflesso della dinamica dell'acqua (The dynamics of the living being as the reflection of water dynamics). "La medicina biologica", 2010/4: 21-27. 
18. Freeman W. J., Vitiello G., Nonlinear brain dynamics as macroscopic manifestation of underlying many-body field dynamics, "Physics of Life Reviews" 2006, 3 (2): 93-118.

19. Freeman W.J., Vitiello G., Dissipation and spontaneous symmetry breaking in brain dynamics, "Journal of Physics A: Mathematical and Theoretical" 2008, 41 (30), 304042.

20. Goldstone J., Salam A., Weinberg S, Broken Symmetries, "Physical Review" 1962, 127, 965 (doi.org/10.1103/PhysRev.127.965).

21. Heller M., Filozofia nauki. Wprowadzenie. Kraków 2009.

22. Heller M., Otwarte perspektywy świata myśli i świata przyrody, [w:] Wszechświat Maszyna czy myśl, M. Heller, J. Życiński i in., Kraków 2014.

23. Heller M., Bóg i materia, [w:] Wszechświat - Maszyna czy myśl, M. Heller, J. Życiński i in., Kraków 2014.

24. International Research Area on Foundations of Science. 2017. IRAFS Newsletter 1 (2016): 7-10. Dostęp: 26 listopada 2017. http://www.irafs.org/materials/2016 nl1_eng.pdf.

25. Itzykson C., Zuber J., Quantum field theory, New York 1980.

26. Manganaro P., Phenomenology and Neuroscience. Living Experience, Empathy and Embodied simulation, [w:] COMPRENDRE. Archive International pour l'Anthropologie et la Psychopathologie Phénoménologiques, Padova 2010, s. 153-165.

27. Maritain J., Distinguere per unire. I gradi del sapere, Brescia 1974.

28. Montalenti G., From Aristotle to Democritus via Darwin, [w:] Studies in the Philosophy of Biology, F.J. Ayala, T. Dobzhansky (red.), London 1974, s. 3-19.

29. Mutschler H.-D., Wprowadzenie do filozofii przyrody, tłum. J. Bremer, Kraków 2005, s. 134-139.

30. Newton I., Opticks, London 1730.

31. Newton I., Scolio generale, [w:] Principi matematici della Filosofia Naturale, A. Pala (red.), Milano 2008.

32. Pabjan T., Złożoność i samoorganizacja, [w:] Wszechświat - Maszyna czy myśl, M. Heller, J. Życiński i in., Kraków 2014.

33. Pabjan T., Niedomknięty bilans wszechświata. Kraków 2016.

34. Planck M., La posizione della nuova fisica di fronte alla visione meccanicistica della natura, [w:] Scienza, filosofia e religione, F. Selvaggi (red.), Milano 1965, s. 147-165.

35. Prigogine I., Stengers I., Order out of chaos. Man's new dialogue with nature, Bantam Books 1984.

36. Prigogine I., Le leggi del caos, Roma - Bari 2008.

37. Sanguineti J. J., Operazioni cognitive: un approccio ontologico al problema mente-cervello, "Acta Philosophica" II, 14 (2005), s. 233-258.

38. Tomasz z Akwinu, Summa theologiae. Rzym 1962. [Tłumaczenie polskie: Tomasz z Akwinu. Traktat O Człowieku. Kęty 2000.]

39. Tomasz z Akwinu, Expositio libri Posteriorum Analyticorum w Corpus Thomisticum 2000.

40. S. Thomae de Aquino, Opera Omnia, E. Alarcón (red.), Pamplona, www.corpusthomisticum.org. 
41. Tomasz z Akwinu, In libros Physicorum, [w:] Corpus Thomisticum. S. Thomae de Aquino, Opera Omnia 2000, E. Alarcón (red.), Pamplona, www.corpusthomisticum.org.

42. Tomasz z Akwinu. De Potentia [w:] Corpus Thomisticum. S. Thomae de Aquino, Opera Omnia 2000, E. Alarcón (red.), Pamplona, www.corpusthomisticum.org.

43. Umezawa H., Advanced field theory: micro, macro and thermal concepts, New York 1993.

44. Vitiello G., Coherent states, fractals and brain waves, "New Mathematics and Natural Computing" 2009, 5 (1): 245-264.

45. Vitiello G., Stati coerenti e domini coerenti nella fisica della materia vivente (Coherent states and coherent domains in the physics of the living matter), "La medicina biologica" 2010/4: 13-19. 